\title{
A Kénosis de Jesus como Autocomunicação do Pathos de Deus: um estudo da kénosis a partir de teologia de Jürgen Moltmann
}

\author{
Orientador: Paulo Cezar Costa
}

Mestrando: Rafael da Silva Sampaio

Área de Concentração: Teologia Sistemático-Pastoral

Linha de Pesquisa: Fé e Cultura

A kénosis de Jesus evidencia o ser profundo de Deus - pathos. Ela revela, no esvaziamento de Cristo - esvaziamento obediente ao Pai até morte de cruz -, que o Deus das escrituras é um Deus passível, próximo à humanidade em seu sofrimento, é amor e por ser amor - apaixonado e "sofredor" - sofre com os sofrimentos de sua criação. Seu sofrimento, no entanto, não constitui uma carência de seu ser, mas sua onipotência no amor. O pathos de Deus evidenciado na kénosis de Jesus difere, em absoluto, do deus da filosofia clássica, cuja existência implica a ordenação do mundo como um motor imóvel ou como o sujeito absoluto da modernidade que recebe a subjetividade de sua criação, portanto, um deus "apático", indiferente às vicissitudes da história humana. Jesus, em sua kénosis, revela o ser humano como o evento da gratuita autocomunicação de Deus e no ponto culminante de seu esvaziamento - abandono e morte de cruz - acolhe os sofredores, justifica os ímpios e vivifica os mortos em sua comunhão com o Pai e com o Espírito que procede dessa comunhão amorosa. Sendo assim, os objetivos desse trabalho são: proporcionar uma nova perspectiva para a compreensão de Deus, que norteia a fé cristã, através de Jesus Cristo. Este em sua vida e profunda intimidade autocomunica o pathos de Deus e isso pôde ser constatado nesta pesquisa a partir dos diversos livros e artigos consultados para o desenvolvimento deste trabalho. Portanto, concluímos que Jesus em sua kénosis autocomunica o pathos de Deus.

Palavras-chave: Kénosis. Jesus Cristo. Autocomunicação. 